\title{
Effect of Suckling Management and Ewe Concentrate Level on Methane-Related Carbon Footprint of Lamb Meat in Sardinian Dairy Sheep Farming
}

\author{
Gianni Battacone (D), Mondina Francesca Lunesu *(D), Salvatore Pier Giacomo Rassu, Anna Nudda (D) \\ and Giuseppe Pulina $\mathbb{D}$
}

check for updates

Citation: Battacone, G.; Lunesu, M.F.; Rassu, S.P.G.; Nudda, A.; Pulina, G. Effect of Suckling Management and Ewe Concentrate Level on

Methane-Related Carbon Footprint of Lamb Meat in Sardinian Dairy Sheep Farming. Animals 2021, 11, 3605. https://doi.org/10.3390/ani11123605

\section{Academic Editors:}

Antonino Di Grigoli

and Adriana Bonanno

Received: 2 December 2021

Accepted: 18 December 2021

Published: 20 December 2021

Publisher's Note: MDPI stays neutral with regard to jurisdictional claims in published maps and institutional affiliations.

Copyright: (c) 2021 by the authors. Licensee MDPI, Basel, Switzerland. This article is an open access article distributed under the terms and conditions of the Creative Commons Attribution (CC BY) license (https:// creativecommons.org/licenses/by/ $4.0 /)$.
Dipartimento di Agraria, Sezione di Scienze Zootecniche, University of Sassari, Viale Italia 39, 07100 Sassari, Italy; battacon@uniss.it (G.B.); pgrassu@uniss.it (S.P.G.R.); anudda@uniss.it (A.N.); gpulina@uniss.it (G.P.)

* Correspondence: mflunesu@uniss.it; Tel.: +39-079-229-308

Simple Summary: Suckling lamb meat is the secondary product of the Mediterranean traditional dairy sheep industry. Similar to the main production, i.e., milk, lamb meat contributes to the emission of greenhouse gases (GHG), whose main portion is represented by enteric methane produced by the lamb dams. Such an emission, although limited in quantitative terms, should be mitigated by appropriate feeding or compensation techniques. Among all the sources of variation of meat lamb emissions, sex of the lamb and type of lambing (single or twins) showed the largest effect.

Abstract: The aim of this study was to estimate the methane-linked carbon footprint (CF) of the suckling lamb meat of Mediterranean dairy sheep. Ninety-six Sarda dairy ewes, divided into four groups of 24 animals each, were assigned to $2 \times 2$ factorial design. The experiment included the suckling lamb feeding system: traditional (TS), in which lambs followed their mothers on pasture during grazing time, vs. separated (SS), in which lambs remained indoors, separated from their mothers during the grazing time. Each group was divided into high (HS) and low (LS) supplemented ewes $\left(600 \mathrm{~g} / \mathrm{d}\right.$ vs. $200 \mathrm{~g} / \mathrm{d}$ of concentrate). The estimated $\mathrm{CH}_{4}$ emission of the ewes, calculated per $\mathrm{kg}$ of body weight (BW) gain of the lamb during the suckling period, was then converted to $\mathrm{CO}_{2}$ eq with multiplying factor of 25 . The TS lambs showed lower methane-linked emissions than SS ones $(p<0.05)$. The sex of lambs affected their methane-linked CF, with males having lower $(p<0.05)$ values than females. Twins displayed much lower methane-linked CF than singles $(4.56 \mathrm{vs} .7 .30 \mathrm{~kg}$ of $\mathrm{CO}_{2}$ eq per $\mathrm{kg}$ of BW gained), whereas the level of supplementation did not affect greenhouse gases (GHG) emission. Interaction displayed lower and not-different GHG emissions for both indoorand outdoor-reared twins. In conclusion, the methane-linked CF of the suckling lamb meat can be reduced by maintaining the traditional lamb rearing system and by improving flock prolificacy.

Keywords: carbon footprint; suckling lamb; extensive system; Mediterranean region

\section{Introduction}

Dairy lamb is a secondary product of dairy sheep farms, and it is consumed mostly in Mediterranean countries [1]. It represents a niche product appreciated by consumers for its nutritional and organoleptic characteristics, due to both the young slaughtering age (4-6 weeks of age) and the quality of maternal milk obtained mainly by grazing natural pastures [2]. Moreover, the suckling lamb meat is an interesting source of fatty acids of nutritional importance [3] and it is particularly suitable for children's diets, especially in the weaning phase $[4,5]$.

Growing concerns of European citizens about the environmental impact of animal productions require that foods must also guarantee sustainability, especially in terms of climate-altering gas emissions [6]. As a consequence, the number of livestock life cycle assessment (LCA) studies has considerably increased in the last two decades [7]. Most 
of this research deals with the environmental sustainability of beef and pork production. Carbon footprint (CF) of lamb meat has received less attention [7], and studies were carried out mostly on the quantification of environmental performance of the heavy lamb with values ranging hugely from 2.8 [8] to 38.45 [9] $\mathrm{kg} \mathrm{CO}_{2}$ eq per $\mathrm{kg}$ of live weight ( $\mathrm{LW}$ [8-18]. All research was carried out in Oceania (most of the studies), in Europe, US, China, and Chile [19]. Most of them quantified greenhouse gases (GHG) emissions by comparing different farming systems, from pasture to zero-grazing [13], from lowland to hill farms [14], from conventional to organic [10], or considering different forage species in pasture-based flock management [20]. Recently, methane production of fattening lambs was predicted by intramuscular fatty acid profile [21].

Most of these studies consider $1 \mathrm{~kg}$ of live weight (LW) as functional unit and, since sheep farms produce two or three coproducts (milk, meat, and wool), economic or a biophysical allocation are generally used to distribute the overall impacts between them [19]. Furthermore, the greater amount of impact in this meat production system occurs at the farm level $(90 \%[9,22])$, and it depends mostly on enteric methane emissions whose relative contribution to total $\mathrm{CF}$ ranges from $58 \%$ [13] to $80 \% \%$ [23]. $\mathrm{CO}_{2 \mathrm{eq}}$ emissions from purchased feeds, energy, and fuel, and $\mathrm{N}_{2} \mathrm{O}$ emissions from soil and manure management, contribute to the total impact in a lesser proportion.

All of these studies deal with meat sheep lamb production, whereas, to the best of the authors' knowledge, the CF of suckling dairy lambs has not been estimated. As recently reviewed by Battacone et al. [3], suckling lambs are fed exclusively maternal milk from birth to slaughter. Thus, this type of production does not require additional inputs than those demanded by their mothers. For these reasons, CF of suckling dairy lamb should be probably lower than values available in the literature.

Feeding technique has been demonstrated to be effective in reducing the CF of milk in dairy cows [24-26], goats [25,27], and sheep [25-27]. Methane emission per unit of milk or meat has continuously decreased during the last decades, and it is expected to continue this trend [28]. Thus, it is reasonable to hypothesize that feeding techniques implemented to reduce the environmental impact of dairy ewes could also influence the CF of suckling lamb meat. In fact, the feeding regimen influences ewe dry matter intake (DMI) and, consequently, the methane yield (the principal GHG produced by sheep).

In this work the CF of suckling lambs under different management systems and mother feeding was estimated by considering exclusively the $\mathrm{CO}_{2}$ eq derived from the $\mathrm{CH}_{4}$ emitted by the ewes during the suckling period. This choice assumed that methane emissions related to gestation and replacement can be totally attributed to milk production, which is the main activity of the farm, with an allocation of $100 \%$ of all other emissions to this production. Such a strong assumption was made in order to simplify calculations and to make the comparison between different production systems easier, without altering the overall impacts of sheep dairy farms.

Aim: The aim of this work was to estimate the methane-linked carbon footprint (CF) of the suckling lamb meat of Mediterranean dairy sheep.

\section{Materials and Methods}

The CF of suckling lambs was estimated using data collected in a commercial dairy sheep farm located in the northwest of Sardinia (Italy). The animal protocol was carried out in compliance with the EU and Italian regulation on animal welfare. For this study, no animals were specifically killed for experimental purposes; however, data at commercial slaughter were collected. University ethics approval was also not required.

\subsection{Experimental Procedure: Animals and Diet}

The experiment involved ninety-six Sarda nursing ewes (body weight (BW): $46.33 \pm 0.40 \mathrm{~kg}$; mean \pm standard error) who were monitored with their lambs for a period of 28 days. The trial started immediately after lambing. In Sardinian dairy sheep farming, there are two lambing 
seasons: autumn for pluriparous, and spring for primiparous. In this trial, only pluriparous ewes were chosen, so lambing was concentrated at mid-November.

A sample of 100 ewes lambing with parturition occurring within two days were selected from the flock and serially numbered. Then, 96 animals were extracted and randomly assigned to four groups of 24 animals each in a $2 \times 2$ factorial design:

(a) Traditional system with high supplementation (TS-HS), in which mothers were followed by suckling lambs during the grazing time and they received a high dose of supplement ( $600 \mathrm{~g} / \mathrm{d}$ of concentrate).

(b) Traditional system with low supplementation (TS-LS), in which mothers were followed by suckling lambs during the grazing time and they received a low dose of supplement (200 g/d of concentrate).

(c) Separated system with high supplementation (SS-HS), in which mothers were not followed by suckling lambs during the grazing time (suckling lambs remained indoors) and they received a high dose of supplement $(600 \mathrm{~g} / \mathrm{d}$ of concentrate).

(d) Separated system with low supplementation (SS-LS), in which mothers were not followed by suckling lambs during the grazing time (suckling lambs remained indoors) and they received a low dose of supplement ( $200 \mathrm{~g} / \mathrm{d}$ of concentrate).

The ewes grazed daily on a lush pasture for $6 \mathrm{~h}$ (9:30 a.m. to 15:30 p.m.). The concentrate was offered during two daily meals. In addition, all ewes had ad libitum access to hay during the night. The chemical composition of feeds offered is showed in Table 1.

Table 1. Chemical composition of feeds offered to nursing ewes.

\begin{tabular}{cccc}
\hline & Concentrate $^{\mathbf{1}}$ & Hay & Pasture \\
\hline DM, \% as fed & 87.2 & 91.0 & 22.3 \\
CP, \% on DM & 17.0 & 5.0 & 18.2 \\
NDF, \% on DM & 41.5 & 61.0 & 42.5 \\
ADF, \% on DM & 20.7 & 50.0 & 25.2 \\
ADL, \% on DM & 5.3 & 5.0 & 3.0 \\
Ash, \% on DM & 9.8 & 7.9 & 10.4 \\
EE, \% on DM & 2.4 & 1.9 & 1.5 \\
\hline
\end{tabular}

$\overline{\mathrm{DM}}=$ dry matter; $\mathrm{CP}=$ crude protein; $\mathrm{NDF}=$ neutral detergent fiber; $\mathrm{ADF}=$ acid detergent fiber; $\mathrm{ADL}=$ acid detergent lignin; EE = ether extract. ${ }^{1}$ The concentrate was composed of the following ingredients: wheat bran, soybean hulls (from genetically modified soybean), alfalfa meal, wheat distilled dried grains, wheat bran, sunflower extraction meal, maize germ cake, dried sugar beet pulp, hydrogenated vegetable fatty acid, corn gluten meal, molasses sugar beet, calcium carbonate from limestone rocks, soybean cake, maize. Vitamin supplement: A,

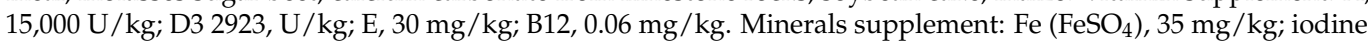
$\left(\mathrm{Ca}\left(\mathrm{IO}_{3}\right)_{2}\right), 1.1 \mathrm{mg} / \mathrm{kg} ; \mathrm{MnO}, 70 \mathrm{mg} / \mathrm{kg} ; \mathrm{Se}\left(\mathrm{Na}_{2} \mathrm{SeO}_{3}\right), 0.51 \mathrm{mg} / \mathrm{kg} ; \mathrm{ZnO}, 70 \mathrm{mg} / \mathrm{kg} ; \mathrm{Mo}\left(\mathrm{Na}_{2} \mathrm{MoO}_{4}\right), 1.0 \mathrm{mg} / \mathrm{kg}$.

The newborn lambs ( $n=44$ females and 52 males) were fed exclusively maternal milk throughout the whole experimental period (28 days). At 28 days of age, they were weighed and then slaughtered in an authorized commercial abattoir.

\subsection{Measurements and Sampling}

During the experimental period, BW of ewes was measured weekly by using an electronic scale. Lamb weight was measured at birth and then once a week until slaughter. Average daily gain was calculated.

Individual milk yield was measured on the two consecutive days after slaughter (two times per day, at morning and evening milking) to confirm the estimation of milk produced by the dams in function of daily growth of lambs. Individual milk samples ( $n=384 ; 96$ per treatment) were also collected and analyzed for chemical composition.

Samples of grass, hay, and concentrate were collected weekly for chemical analysis.

\subsection{Chemical Analyses}

Milk samples were analyzed for fat, protein, lactose (infrared method; Milkoscan 4000, Foss Eletric, Hillerød, Denmark), urea content (enzymatic-colorimetric method based on Berthelot reaction; Chemspec 150, Bentley Instruments Inc., Chaska, MN, USA), 
and somatic cell count (SCC, flow-cytometry method; Fossomatic 5000, Foss Electric, Hillerød, Denmark).

Feed samples were ground with a Hammer mill by using a $1 \mathrm{~mm}$ screen, and then analyzed for DM, CP (Kjeldahl method; AOAC International, [29]; method 988.05), NDF, ADF, ADL (including termostable-amylase and following the method of Van Soest et al. [30]), ether extract (EE; Soxlet, AOAC International, [31]; method 920.39), and ash (AOAC International, [29]; method 942.05) after drying at $105^{\circ} \mathrm{C}$.

\subsection{Carbon Footprint Assessment, System Boundary, Functional Unit, and Allocation Method}

The $\mathrm{CH}_{4}$-linked carbon footprint was calculated within a cradle to farm gate system boundary considering maternal enteric $\mathrm{CH}_{4}$ emissions and milk suckled by the lambs as the main emissions hotspots. Data collected during the experimental trial were used to estimate maternal DMI [32] as follows:

$$
\mathrm{I}=-0.545+0.095 \mathrm{MW}+0.65 \mathrm{FPCM}+0.0025 \mathrm{BWC}
$$

where $\mathrm{I}=\mathrm{DMI}$ in $\mathrm{kg} / \mathrm{head} \mathrm{day}^{-1}$; MW = metabolic weight $\left(\mathrm{BW}^{0.75}\right)$ in $\mathrm{kg}$; $\mathrm{BWC}=$ bodyweight change in $\mathrm{g} /$ day; FPCM $=$ fat $(\mathrm{F}=6.5 \%)$ and protein $(p=5.8 \%)$ corrected milk (M) in $\mathrm{kg}$ which, in turn, was calculated as:

$$
\mathrm{FPCM}=\mathrm{M}(0.25+0.085 \mathrm{~F}+0.035 \mathrm{P})(\mathrm{kcal} / \mathrm{kg}=1047)
$$

where $\mathrm{M}=$ milk yield in $\mathrm{kg} ; \mathrm{F}$ and $p=$ fat and protein concentration in \%, [33].

Milk suckled by the lamb was estimated at $5.376 \mathrm{~kg} / \mathrm{kg}$ of BW growth (BWG), arranging the Pulina et al. [34] equation which estimates the daily milk production of dams (M) in g/day as function of BWG (in g/day) and MBW of lambs (in kg):

$$
\mathrm{M}=140.6+4.52 \mathrm{BWG}-0.705 \mathrm{MBW}
$$

Methane emissions were then estimated by using the equation 10.21 of the Intergovernmental Panel on Climate Change (IPCC) guidelines for national GHG inventories [35]:

$$
\mathrm{EF}=\mathrm{GE}(\mathrm{Ym} / 100) / 55.65
$$

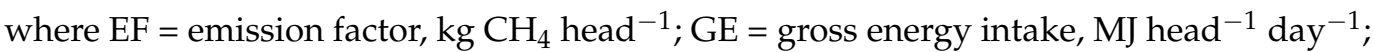
$\mathrm{Ym}=$ methane conversion factor, per cent of gross energy in feed converted to methane; the factor $55.65\left(\mathrm{MJ} / \mathrm{kg} \mathrm{CH}_{4}\right)$ is the energy content of methane.

The estimated $\mathrm{CH}_{4}$ emission of the ewes was then expressed in terms of $\mathrm{CO}_{2}$ eq where $1 \mathrm{~kg} \mathrm{CH} \mathrm{CH}_{4}=25 \mathrm{~kg} \mathrm{CO}$ eq in accordance with the global warming potential of emissions defined by the IPCC guidelines. Finally, the $\mathrm{CH}_{4}$-linked $\mathrm{CF}$ was calculated considering $1 \mathrm{~kg}$ of BW gain (during the suckling period) as functional unit (FU) and applying no allocation factor.

\subsection{Statistical Analysis}

Ewe DMI data were analyzed with the following linear model:

$$
\mathrm{DMI}=\mu+\mathrm{G}+\mathrm{C}+\mathrm{P}+1 \text { st_inter }+\varepsilon
$$

where DMI (in $\mathrm{kg}$ ) is the total 28 days intake during the suckling period, $\mathrm{G}$ is the lamb management (TS vs. SS), $\mathrm{C}$ is the supplement level (HS vs. LS), $\mathrm{P}$ is the kind of lambing (single vs. twins, no triplets were admitted to the experiment), and 1st_inter are the first order interactions between the couples of experimental factors.

Birth weight, slaughter weight, average daily gain (ADG), and $\mathrm{CH}_{4}$-linked $\mathrm{CF}$ of lambs were analyzed with the following linear model:

$$
Y=\mu+G+C+P+S+1 \text { st_inter }+\varepsilon
$$


where $\mathrm{Y}$ is the dependent variable, $\mathrm{G}$ is lamb management (TS vs. SS), $\mathrm{C}$ is the supplement level (HS vs. LS), $\mathrm{P}$ is the kind of lambing (single vs. twins, no triplets were admitted to the experiment), $\mathrm{S}$ is the sex of lamb, and 1st_inter are the first order interactions between the couples of experimental factors.

Differences between means were detected with Tukey test, and significative level was declared for $p<0.05$ [36].

\section{Results and Discussion}

Milk production of ewes in the first control after lamb slaughter were $1.36 \pm 0.074 \mathrm{~kg} / \mathrm{d}$ (mean \pm standard error) for TS-HS group, $1.19 \pm 0.075 \mathrm{~kg} / \mathrm{d}$ for TS-LS group, $1.28 \pm 0.074 \mathrm{~kg} / \mathrm{d}$ for SS-HS group, and $1.32 \pm 0.075 \mathrm{~kg} / \mathrm{d}$ for SS-LS group. They were slightly lower than those estimated by using Equation (3) (TS-HS: $1.68 \pm 0.095 \mathrm{~kg} / \mathrm{d}$, TS-LS: $1.46 \pm 0.069 \mathrm{~kg} / \mathrm{d}$, SS-HS: $1.32 \pm 0.092 \mathrm{~kg} / \mathrm{d}$, SS-LS: $1.35 \pm 0.068 \mathrm{~kg} / \mathrm{d}$; mean \pm standard error) because milking normally produces slightly less milk than suckling.

\subsection{Suckling Lambs Performance at Birth and after the Suckling Period}

Data on birth body weight, body weight at slaughter, and ADG are shown in Table 2.

Table 2. Least-squares means for initial body weight (birth weight), final body weight (at slaughter after 28 days suckling period), and average daily gain (ADG) of Sarda suckling lambs.

\begin{tabular}{|c|c|c|c|c|c|c|}
\hline & \multicolumn{2}{|c|}{ Birth Weight (kg) } & \multicolumn{2}{|c|}{ Slaughter Weight (kg) } & \multicolumn{2}{|c|}{ ADG (kg/d) } \\
\hline & Mean & $\mathrm{SE}^{1}$ & Mean & SE & Mean & SE \\
\hline \multicolumn{7}{|l|}{ Lamb Management } \\
\hline Traditional & 3.98 & 0.08 & 10.20 & 0.20 & 0.22 & 0.006 \\
\hline Indoor & 4.03 & 0.08 & 9.37 & 0.21 & 0.19 & 0.007 \\
\hline$p$-value & 0.575 & & 0.004 & & $<0.001$ & \\
\hline \multicolumn{7}{|l|}{$\begin{array}{c}\text { Ewes' Supplement } \\
\text { Level }\end{array}$} \\
\hline Low (200 g/d/ewe) & 3.90 & 0.08 & 9.78 & 0.21 & 0.21 & 0.007 \\
\hline High (600 g/d/ewe) & 4.10 & 0.08 & 9.79 & 0.21 & 0.20 & 0.007 \\
\hline$p$-value & 0.812 & & 0.170 & & 0.158 & \\
\hline \multicolumn{7}{|l|}{ Type of Lambing } \\
\hline Single & 4.28 & 0.06 & 10.82 & 0.17 & 0.23 & 0.005 \\
\hline Twins & 3.73 & 0.04 & 8.76 & 0.27 & 0.18 & 0.008 \\
\hline$p$-value & $<0.001$ & & $<0.001$ & & $<0.001$ & \\
\hline \multicolumn{7}{|l|}{ Sex of Lamb } \\
\hline Male & 4.12 & 0.080 & 10.17 & 0.20 & 0.22 & 0.006 \\
\hline Female & 3.88 & 0.084 & 9.40 & 0.22 & 0.20 & 0.007 \\
\hline$p$-value & 0.010 & & 0.038 & & 0.225 & \\
\hline Mean 2 & 4.14 & 0.061 & 10.32 & 0.18 & 0.22 & 0.005 \\
\hline
\end{tabular}

The first-order interactions between the couples of experimental factors were never significant $(p>0.05)$, except for lamb management $\mathrm{x}$ type of lambing interaction for $\mathrm{kg}$ $\mathrm{CO}_{2} \mathrm{eq} / \mathrm{kg}$ lamb BW gain. Mother's supplement level did not affect lamb birth weight. The lamb management significantly affected body weight at slaughter $(p<0.01)$ and the ADG $(p<0.001)$. TS Lambs exhibited higher slaughter weights and ADG compared to SS lambs, probably because they could suckle more times a day from their mother than SS. Such a larger amount of milk received by TS lambs compensated the higher energy expenditure for movement and thermoregulation needed to follow the mothers during grazing.

Concerning the type of lambing, our data evidenced that single-born lambs had higher birth weight $(p<0.01)$, birth weight at slaughter $(p<0.001)$, and ADG $(p<0.01)$ compared to twins. These results are comparable to those observed in previous studies in which single lambs showed higher live weight than twin lambs both at birth and later on [37,38], and tended to grow faster than those with lower live weight at birth [38]. 
Regarding the sex, male lambs had higher birth weight $(p<0.01)$, birth weight at slaughter $(p<0.01)$, and ADG $(p<0.01)$ compared to female lambs. Generally, at birth, males show higher birth weight than females [39-41]; this difference has been reported for several breeds, and it seems to persist during the life [42]. Other studies did not find differences between sexes at birth, but they evidenced that male lambs tend to grow faster than females [38].

\subsection{Carbon Footprint of Suckling Lambs}

In the present study, $\mathrm{CH}_{4}$-linked $\mathrm{CF}$ of suckling lamb varied between 4.56 and $7.30 \mathrm{~kg}$ $\mathrm{CO}_{2} \mathrm{eq} / \mathrm{kg}$ lamb BW gain, respectively. A comparison with other studies is quite difficult because of the lack of research on the estimation of CF of suckling lambs and also because of the methodological heterogeneity among studies. However, from our data, it is possible to observe a strong relationship between $\mathrm{CH}_{4}$-linked $\mathrm{CF}$ of suckling lamb and $\mathrm{BW}$ gain of lambs (Figure 1), in agreement with the relationships between GHG emissions and the $\mathrm{kg}$ of LW or BW gain observed in sheep meat breeds [43-46].

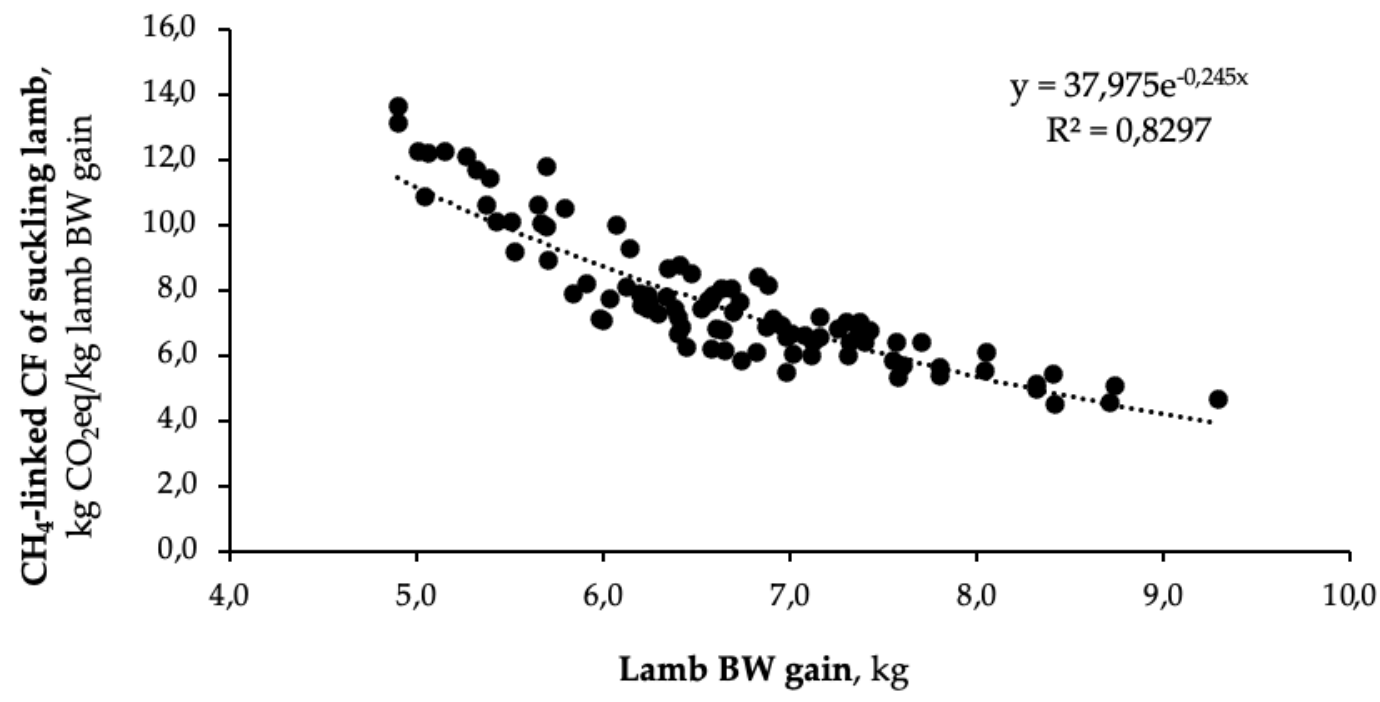

Figure 1. Allometric relation between $\mathrm{CH}_{4}$-linked carbon footprint (CF) of suckling lamb and lamb body weight (BW) gain.

The estimation of total DMI of ewes and $\mathrm{CH}_{4}$-linked $\mathrm{CF}$ of suckling lambs are reported in Table 3.

Ewes of TS showed higher $(p<0.01)$ total DMI as a consequence of their higher milk production, caused by the higher frequency of suckling activities of the lambs. In fact, lambs following their mothers all day around matched their ethological behavior, compared to lambs kept indoors that had the possibility to suckle only during the night. Increasing the frequency of suckling in TS lambs caused more frequent udder-emptying, which stimulates milk secretion [47]. The lower $\mathrm{CH}_{4}$-linked $\mathrm{CF}$ of TS lambs compared to SS $(p<0.05)$ could be therefore explained by the fact that the higher DMI of mothers is diluted in a greater BW gain of their offspring (Figure 2).

The level of supplement used did not affect the DMI of ewes or the $\mathrm{CH}_{4}$-linked CF of suckling lambs. In this sense, very few studies have evaluated the effect of concentrate supplementation in animals under grazing conditions. Commonly, a negative relationship between $\mathrm{CH}_{4}(\mathrm{~g} / \mathrm{kg} \mathrm{DMI})$ and level of concentrate in the diet has been reported in beef cattle [48] and lambs [49], and the use of concentrates has been proposed as a valid mitigation strategy for ruminants [50]. In the current study, the results are likely explained by the lack of substitution effect of supplement on pasture, because of the similar nutrient composition of grass and supplement. This is in agreement with a study conducted in dairy cows under high-quality grazing conditions where the increase in concentrate supplementation resulted in a simultaneous increase in enteric methane emissions and 
milk production, and so considering that methane emissions are expressed per unit of milk yield, the effect of supplement on GHG mitigation was not evident [51].

Table 3. Least-squares mean for total dry matter intake (DMI) of ewes and $\mathrm{CH}_{4}$-linked carbon footprint of lambs (expressed in $\mathrm{kg}$ of $\mathrm{CO}_{2} \mathrm{eq} / \mathrm{kg}$ of $\mathrm{BW}$ gain) during 28-day suckling period.

\begin{tabular}{ccccc}
\hline & \multicolumn{2}{c}{ Total DMI of Ewes $\mathbf{( k g})$} & \multicolumn{2}{c}{$\mathbf{k g ~ C O}$ eq/kg Lamb BW Gain } \\
\cline { 2 - 5 } & Mean & $\mathbf{S E}^{\mathbf{1}}$ & Mean & SE \\
\hline Lamb Management & & & & \\
Traditional & 63.26 & 1.03 & 5.67 & 0.15 \\
Indoor & 58.42 & 1.02 & 6.20 & 0.16 \\
$p$-value & 0.001 & & 0.016 & \\
Ewes' Supplement & & & & \\
Level & & & 5.77 & 0.16 \\
Low (200 g/d/ewe) & 60.83 & 1.13 & 6.10 & 0.15 \\
High (600 g/d/ewe) & 60.85 & 0.95 & 0.137 & \\
$p$-value & 0.988 & & & \\
Type of Lambing & & & 7.30 & 0.15 \\
Single & 50.79 & 0.78 & 4.56 & 0.17 \\
Twins & 66.89 & 1.25 & $<0.001$ & \\
$p$-value & $<0.001$ & & & \\
Sex of Lamb & & & 5.70 & 0.16 \\
Male & & & 0.16 & 0.16 \\
Female & & & 0.038 & \\
$p$-value & & & & \\
\hline
\end{tabular}

${ }^{1} \mathrm{SE}=$ standard error.

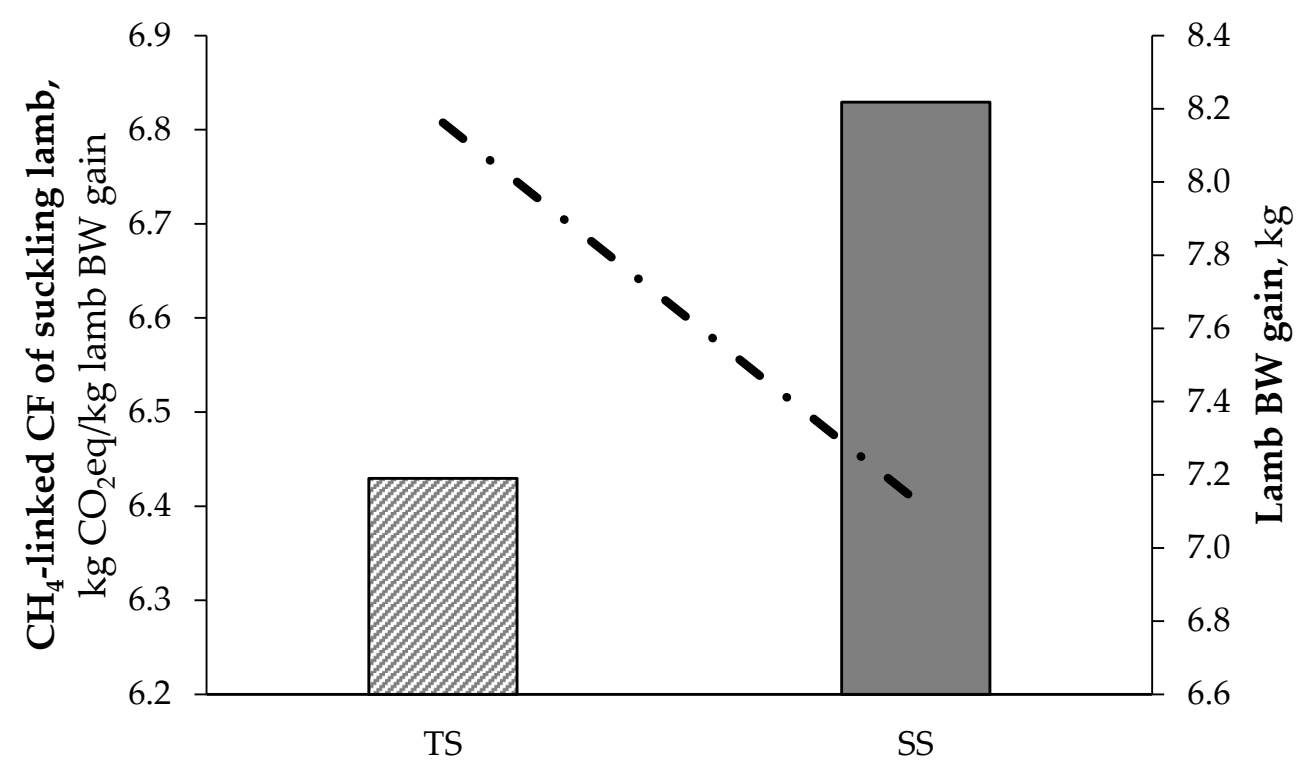

Figure 2. Methane-linked carbon footprint (CF) and lamb body weight (BW) gain in suckling lambs raised in the traditional (TS) and separated systems (SS).

Previous studies carried out in lambs evidenced that varying the proportion of concentrate did not affect $\mathrm{CH}_{4}$ emissions in lambs fed a basal diet composed of high-quality forages [52]. This suggests that the positive reduction of $\mathrm{CH}_{4}$ per $\mathrm{kg}$ of DMI due to an increase of concentrate amount in the diets could be, in part, counterbalanced by the higher intake of high-quality forages. The findings of the present study suggest that high-quality pasture could act in the same way as concentrates in reducing $\mathrm{CH}_{4}$ emissions. In fact, several studies conducted on beef cattle [53] and sheep [54] farmed in grazing systems with different pasture quality evidenced that high-quality grass can reduce $\mathrm{CH}_{4}$ emissions per 
unit of DMI $\left(\mathrm{CH}_{4} / \mathrm{kg}\right.$ DMI) in comparison with low-quality grass. The positive effect of high-quality pasture on the reduction of enteric $\mathrm{CH}_{4}$ emissions is due to the lower content of NDF, to the high content of $\mathrm{CP}$, and to the higher digestibility [55]. The quantity of fresh forages offered can also have an effect: in fact, CF is lower in high, rather than in low, productive grazing systems [9]. Thus, the improvement of pasture (both in quality and quantity) can be considered a good mitigation strategy to implement at a farm level for reducing enteric methane emissions of ruminants under grazing condition [50,55]. In addition, the use of pasture contributes to reducing the consumption of off-farm feeds and the management of pasture increases soil's carbon sequestration [23].

Twin-lambing ewes showed higher $(p<0.001)$ DMI than ewes with single lambs, probably because of their higher milk production. It is widely assessed that ewes with twins produce more milk than ewes with single lambs [56]. This is due to both the action of the placental lactogenic hormone, whose secretion is proportional to the weight of the placenta and that stimulates greater mammary growth [57], and to the more frequent and complete emptying of the mammary gland [58,59]. As twin-lambing ewes produced more milk, the $\mathrm{CH}_{4}$-linked $\mathrm{CF}$ of their lambs was markedly lower than that of single lambs; this result is also due to sharing of the maintenance requirements of mothers between the twins. The relation between CH4-linked CF of suckling lambs and lamb BW gain in twins compared to single-born lambs is shown in Figure 3.

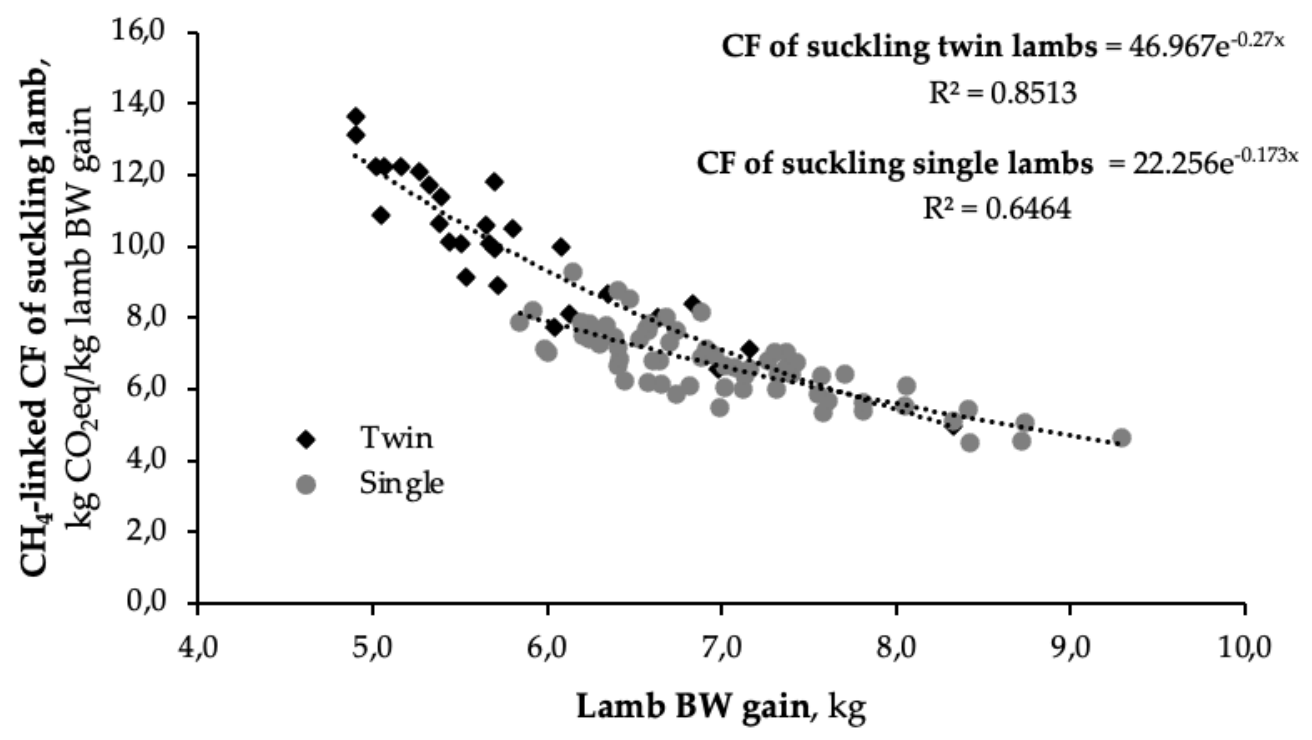

Figure 3. Allometric relation between $\mathrm{CH}$ 4-linked carbon footprint (CF) of suckling lamb and body weight (BW) gain of twins and single-born lambs.

The $\mathrm{CH}_{4}$-linked $\mathrm{CF}$ of twins did not change with the management system, while that of single lambs was lower when they followed the mother on pasture, as evidenced by the significant interaction $(p<0.05$; Figure 4$)$.

The sex of lambs affects their $\mathrm{CH}_{4}$-linked CF, with males having lower $(p=0.038)$ values than those of females, due to their highest growth rates which dilute the $\mathrm{CH}_{4}$ emission of the mother into a higher BW at slaughter, as previously shown in Figure 1.

\subsection{Practical Implications}

Since Sarda sheep are fed mainly on pasture, our data suggest that the environmental impact of suckling lamb meat production can be reduced by improving flock prolificacy and maintaining the traditional lamb rearing system. However, these results are affected by the high nutritional value of pasture and of its large availability. 


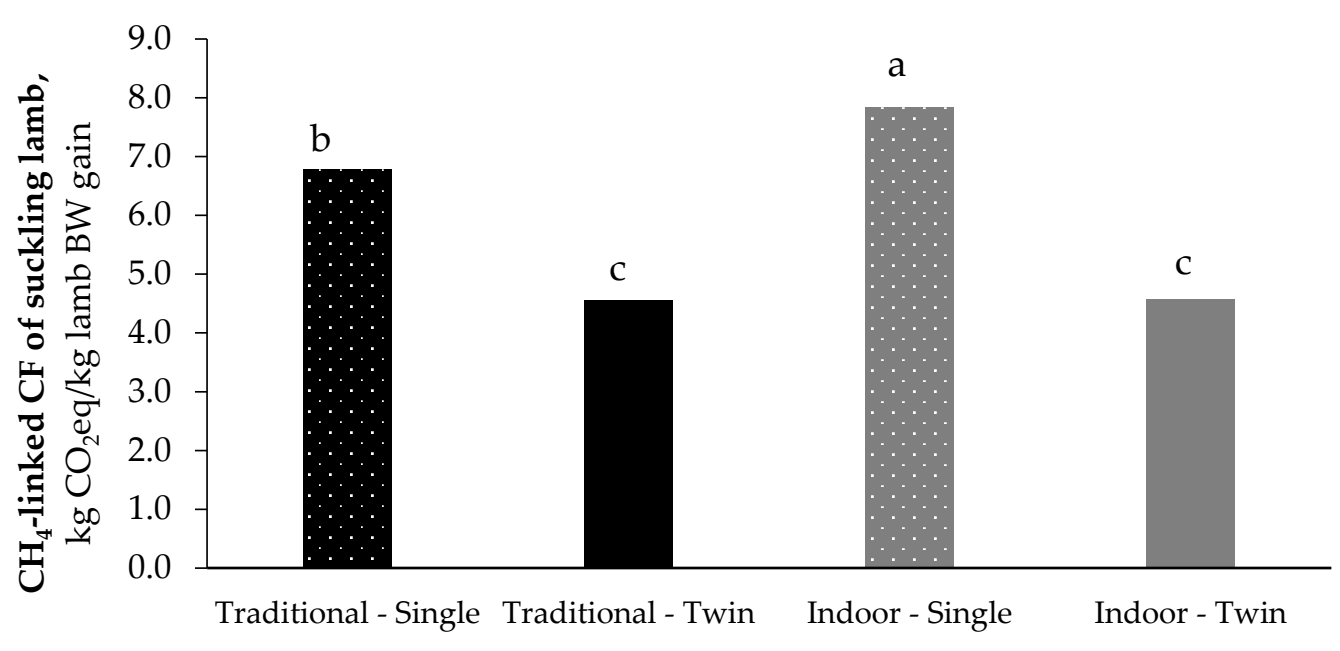

Lamb management $x$ type of lambing interaction

Figure 4. Effect of lamb management $x$ type of lambing interaction on $\mathrm{CH}_{4}$-linked CF (expressed on $\mathrm{kg} \mathrm{CO} 2 \mathrm{eq} / \mathrm{kg}$ lamb BW gain). ${ }^{a, b, c}$ mean values with different superscripts differ $(p<0.05)$ for the interaction between lamb management and type of lambing interaction.

The improvement of forage quality (through the evaluation of the best phenological stage) and forage type (in terms of botanical composition) can be considered as valid mitigation strategies to reduce livestock emissions [26]. Pasture-based systems in the dairy sheep industry are an important tool to mitigate the GHG impact for the capacity of grasslands to sequester $C$ in soil as well as for the ability to provide ecosystem service and animal welfare [26,60-62].

Considering the high diffusion of agro-silvo-pastoral systems in Mediterranean countries where dairy sheep are farmed, new findings on carbon sequestration in soil under pasture management demonstrate that the GHG emissions for suckling lamb meat production can be compensated annually by few $\mathrm{m}^{2}$ of undisturbed pastureland [63].

\section{Conclusions}

Growing concerns about GHG emissions among consumers are driving supply chains to reduce their impacts until the net zero goal is achieved. Not even niche productions, such as dairy lambs linked to traditional pastoral systems, widespread in the Mediterranean area escape this logic. This work, which evaluated only methane emissions from lactating ewes as representative of the GHG impact of dairy lamb meat production, evidenced that the type of suckling management, but not the ewe concentrate level, affected the $\mathrm{CH}_{4}$-linked $\mathrm{CF}$ of lamb meat. Specifically, traditional suckling techniques resulted in a lower $\mathrm{CH}_{4}$-linked $\mathrm{CF}$ of lambs compared to one in which the lambs were separated from their mother during the grazing period. Moreover, a high twinning rate of the flock can be an effective option for reducing the GHG impact.

To conclude, this paper provides the first data on the estimation of environmental impact of the suckling lamb meat production in the Mediterranean region and suggests that to reduce the environmental impact of suckling lamb production systems, lambs could be raised with traditional suckling technique and should be twins.

Some agronomic and livestock practices can be linked to mitigate the GHG impact of dairy sheep industry.

Author Contributions: Conceptualization, G.B., A.N. and G.P.; methodology, M.F.L. and G.P.; validation, S.P.G.R.; data curation, M.F.L.; writing—original draft preparation, G.P.; writing-review and editing, all authors (G.B., M.F.L., S.P.G.R., G.P. and A.N.); funding acquisition, G.B. All authors have read and agreed to the published version of the manuscript. 
Funding: This research was funded by RESTART-UNINUORO Project "Actions for the valorization of agroforestry resources in central Sardinia" Regione Autonoma della Sardegna, fondi FSC 2014-2020.

Institutional Review Board Statement: For this study, University ethics approval was not required since no animals were specifically killed for experimental purposes.

Data Availability Statement: The data presented in this study are available on request from the corresponding author.

Conflicts of Interest: The authors declare no conflict of interest.

\section{References}

1. Pulina, G.; Milán, M.J.; Lavín, M.P.; Theodoridis, A.; Morin, E.; Capote, J.; Thomas, D.L.; Francesconi, A.H.D.; Caja, G. Invited review: Current production trends, farm structures, and economics of the dairy sheep and goat sectors. J. Dairy Sci. 2018, 101, 6715-6729. [CrossRef] [PubMed]

2. D'Alessandro, A.G.; Maiorano, G.; Kowaliszyn, B.; Loiudice, P.; Martemucci, G. How the nutritional value and consumer acceptability of suckling lambs meat is affected by the maternal feeding system. Small Rumin. Res. 2012, 106, 83-91. [CrossRef]

3. Battacone, G.; Lunesu, M.F.; Rassu, S.P.G.; Pulina, G.; Nudda, A. Effect of dams and suckling lamb feeding systems on the fatty acid composition of suckling lamb meat. Animals 2021, 11, 3142. [CrossRef]

4. Cardi, E.; Corrado, G.; Cavaliere, M.; Grandina, G.; Pacchiarotti, C.; Rea, P.; Mazza, M.L.; Nardelli, F.; Agazie, E. Rezza-Cardi's diet as dietary treatment of short bowel syndrome. Gastroenterology 1998, 114, A869. [CrossRef]

5. Martino, F.; Bruno, G.; Aprigliano, D.; Agolini, D.; Guido, F.; Giardini, O.; Businco, L. Effectiveness of a home-made meat based formula (the Rezza-Cardi diet) as a diagnostic tool in children with food induced a topic dermatitis. Pediatric Allergy Immunol. 1998, 9, 192-196. [CrossRef]

6. Arvidsson Segerkvist, K.; Hansson, H.; Sonesson, U.; Gunnarsson, S. A Systematic mapping of current literature on sustainability at farm-level in beef and lamb meat production. Sustainability 2021, 13, 2488. [CrossRef]

7. McClelland, S.C.; Arndt, C.; Gordon, D.R.; Thoma, G. Type and number of environmental impact categories used in livestock life cycle assessment: A systematic review. Livest. Sci. 2018, 209, 39-45. [CrossRef]

8. Edwards-Jones, G.; Plassmann, K.; Harris, I.M. Carbon footprinting of lamb and beef production systems: Insights from an empirical analysis of farms in Wales, UK. J. Agric. Sci. 2009, 147, 707-719. [CrossRef]

9. Peri, P.L.; Rosas, Y.M.; Ladd, B.; Díaz-Delgado, R.; Martinez Pastur, G. Carbon footprint of lamb and wool production at farm gate and the regional scale in southern Patagonia. Sustainability 2020, 12, 3077. [CrossRef]

10. Williams, A.; Audsley, E.; Sandars, D. Determining the Environmental Burdens and Resource Use in the Production of Agricultural and Horticultural Commodities: Defra Project Report 2006, IS0205. Available online: http://randd.defra.gov.uk/Default.aspx (accessed on 6 December 2021).

11. Ledgard, S.F.; Lieffering, M.; Coup, D.; O’Brien, B. Carbon footprinting of New Zealand lamb from the perspective of an exporting nation. Anim. Front. 2011, 1, 40-45. [CrossRef]

12. Bell, M.J.; Eckard, R.J.; Cullen, B.R. The effect of future climate scenarios on the balance between productivity and greenhouse gas emissions from sheep grazing systems. Livest. Sci. 2012, 147, 126-138. [CrossRef]

13. Ripoll-Bosch, R.; De Boer, I.J.M.; Bernués, A.; Vellinga, T.V. Accounting for multi-functionality of sheep farming in the carbon footprint of lamb: A comparison of three contrasting Mediterranean systems. Agric. Syst. 2013, 116, 60-68. [CrossRef]

14. Jones, A.K.; Jones, D.L.; Cross, P. The carbon footprint of lamb: Sources of variation and opportunities for mitigation. Agric. Syst. 2014, 123, 97-107. [CrossRef]

15. O'Brien, D.; Bohan, A.; McHugh, N.; Shalloo, L. A life cycle assessment of the effect of intensification on the environmental impacts and resource use of grass-based sheep farming. Agric. Syst. 2016, 148, 95-104. [CrossRef]

16. Toro-Mujica, P.; Aguilar, C.; Vera, R.R.; Bas, F. Carbon footprint of sheep production systems in semi-arid zone of Chile: A simulation-based approach of productive scenarios and precipitation patterns. Agric. Syst. 2017, 157, 22-38. [CrossRef]

17. Eldesouky, A.; Mesias, F.J.; Elghannam, A.; Escribano, M. Can extensification compensate livestock greenhouse gas emissions? A study of the carbon footprint in Spanish agroforestry systems. J. Clean. Prod. 2018, 200, 28-38. [CrossRef]

18. Dougherty, H.C.; Oltjen, J.W.; Mitloehner, F.M.; DePeters, E.J.; Pettey, L.A.; Macon, D.; Finzel, J.; Rodrigues, K.; Kebreab, E. Carbon and blue water footprints of California sheep production. J. Anim. Sci. 2019, 97, 945-961. [CrossRef]

19. Bhatt, A.; Abbassi, B. Review of environmental performance of sheep farming using life cycle assessment. J. Clean. Prod. 2021, 293, 126192. [CrossRef]

20. Biswas, W.K.; Graham, J.; Kelly, K.; John, M.B. Global warming contributions from wheat, sheep meat and wool production in Victoria, Australia-A life cycle assessment. J. Clean. Prod. 2010, 18, 1386-1392. [CrossRef]

21. Requena Domenech, F.; Gómez-Cortés, P.; Martínez-Miró, S.; de la Fuente, M.Á.; Hernández, F.; Martínez Marín, A.L. Intramuscular fatty acids in meat could predict enteric methane production by fattening lambs. Animals 2021, 11, 2053. [CrossRef]

22. Wiedemann, S.; McGahan, E.; Murphy, C.; Yan, M.J.; Henry, B.; Thoma, G.; Ledgard, S. Environmental impacts and resource use of Australian beef and lamb exported to the USA determined using life cycle assessment. J. Clean. Prod. 2015, 94, 67-75. [CrossRef] 
23. Horrillo, A.; Gaspar, P.; Escribano, M. Organic farming as a strategy to reduce carbon footprint in dehesa agroecosystems: A case study comparing different livestock products. Animals 2020, 10, 162. [CrossRef]

24. Islam, M.; Lee, S.S. Advanced estimation and mitigation strategies: A cumulative approach to enteric methane abatement from ruminants. J. Anim. Sci. 2019, 61, 122. [CrossRef]

25. Min, B.R.; Solaiman, S.; Waldrip, H.M.; Parker, D.; Todd, R.W.; Brauer, D. Dietary mitigation of enteric methane emissions from ruminants: A review of plant tannins mitigation options. Anim. Nutr. 2020, 6, 231-246. [CrossRef] [PubMed]

26. Eugène, M.; Klumpp, K.; Sauvant, D. Methane mitigating options with forages fed to ruminants. Grass Forage Sci. 2021, 76, 196-204. [CrossRef]

27. Marino, R.; Atzori, A.S.; D'Andrea, M.; Iovane, G.; Trabalza-Marinucci, M.; Rinaldi, L. Climate change: Production performance, health issues, greenhouse gas emissions and mitigation strategies in sheep and goat farming. Small Rumin. Res. 2016, 135, 50-59. [CrossRef]

28. Beauchemin, K.A.; Ungerfeld, E.M.; Eckard, R.J.; Wang, M. Fifty years of research on rumen methanogenesis: Lessons learned and future challenges for mitigation. Animal 2020, 14, s2-s16. [CrossRef] [PubMed]

29. AOAC International. Official Method of Analysis, 17th ed.; AOAC International: Arlington, VA, USA, 2000.

30. Van Soest, P.J.; Robertson, J.B.; Lewis, B.A. Methods for dietary fiber, neutral detergent fiber, and nonstarch polysaccharides in relation to animal nutrition. J. Dairy Sci. 1991, 74, 3583-3597. [CrossRef]

31. AOAC International. Official Method of Analysis, 18th ed.; AOAC International: Gaithersburg, MD, USA, 2005.

32. Pulina, G.; Avondo, M.; Molle, G.; Francesconi, A.H.D.; Atzori, A.S.; Cannas, A. Models for estimating feed intake in small ruminants. Rev. Bras. Zootec. 2013, 42, 675-690. [CrossRef]

33. Pulina, G.; Nudda, A. Milk production. In Dairy Sheep Nutrition; Pulina, G., Ed.; CABI Publishing: Wallingford, UK, 2004; Chapter 1; p. 13.

34. Pulina, G.; Rossi, G.; Brandano, P. Stima della Produzione della Pecora in Base al Ritmo di Accrescimento dell'Agnello; Estratto da studi Sassaresi, Sezione III; Annali della Facoltà di Agraria dell'Università di Sassari: Sassari, Italy, 1986; Volume XXXII.

35. IPCC. 2019 Refinement to the 2006 IPCC Guidelines for National Greenhouse Gas Inventories: Chapter 10: Emissions from Livestock and Manure Management; Intergovernmental Panel on Climate Change: Geneva, Switzerland, 2019.

36. Murtaugh, P.A. In defense of $P$ values. Ecology 2014, 95, 611-617. [CrossRef]

37. Ivanova, T.; Raicheva, E. Weight growth at lambs from Blackhead Pleven breed trough suckling period. Agric. Sci. 2009, 42, 11-16.

38. Simeonov, M.; Todorov, N.; Nedelkov, K.; Kirilov, A.; Harmon, D.L. Influence of live weight, sex and type of birth on growth and slaughter characteristics in early weaned lambs. Small Rumin. Res. 2014, 121, 188-192. [CrossRef]

39. Daskiran, I.; Koncagul, S.; Bingol, M. Growth characteristics of indigenous Norduz female and male lambs. J. Agric. Sci. 2010, 16, 62-69.

40. Idris, A.O.; Kijora, C.; El-Hag, F.M.; Salih, A.M. Effect of supplementation on late pregnancy and early lactation of body weight of desert ewes and their lambs. Livest. Res. Rural Dev. 2010, 22, 45-56.

41. Belanche, A.; Cooke, J.; Jones, E.; Worgan, H.J.; Newbold, C.J. Short-and long-term effects of conventional and artificial rearing strategies on the health and performance of growing lambs. Animal 2019, 13, 740-749. [CrossRef]

42. Kumar, S.; Mishra, A.K.; Kolte, A.P.; Arora, A.L.; Singh, D.; Singh, V.K. Effects of the Booroola (FecB) genotypes on growth performance, ewe's productivity efficiency and litter size in Garole $\times$ Malpura sheep. Anim. Reprod. Sci. 2008, 105, 319-331. [CrossRef]

43. Howden, S.M.; Reyenga, P.J. Methane emissions from Australian livestock: Implications of the Kyoto Protocol. Aust. J. Agric. Res. 1999, 50, 1285-1292. [CrossRef]

44. Reid, R.S.; Thornton, P.K.; McCrabb, G.J.; Kruska, R.L.; Atieno, F.; Jones, P.G. Is it possible to mitigate greenhouse gas emissions in pastoral ecosystems of the tropics? In Tropical Agriculture in Transition-Opportunities for Mitigating Greenhouse Gas Emissions? Springer: Dordrecht, The Netherlands, 2004; pp. 91-109.

45. Rabier, F.; Lioy, R.; Paul, C.; Van Stappen, F.; Stilmant, D.; Mathot, M. Assessment of GHG emissions and their variability of meat production systems in Wallonia based on grass and maize. Agric. Agric. Sci. Procedia 2015, 7, 223-228. [CrossRef]

46. McAuliffe, G.A.; Takahashi, T.; Orr, R.J.; Harris, P.; Lee, M.R.F. Distributions of emissions intensity for individual beef cattle reared on pasture-based production systems. J. Clean. Prod. 2018, 171, 1672-1680. [CrossRef]

47. Bar-Peled, U.; Aharoni, Y.; Robinzon, B.; Bruckental, I.; Lehrer, R.; Maltz, E.; Knight, C.; Kali, J.; Folman, Y.; Voet, H.; et al. The effect of enhanced milk yield of dairy cows by frequent milking or suckling on intake and digestibility of the diet. J. Dairy Sci. 1998, 81, 1420-1427. [CrossRef]

48. Ellis, J.L.; Kebreab, E.; Odongo, N.E.; McBride, B.W.; Okine, E.K.; France, J. Prediction of methane production from dairy and beef cattle. J. Dairy Sci. 2007, 90, 3456-3466. [CrossRef] [PubMed]

49. Popova, M.; Morgavi, D.P.; Martin, C. Methanogens and methanogenesis in the rumens and ceca of lambs fed two different high-grain-content diets. Appl. Environ. Microbiol. 2013, 79, 1777-1786. [CrossRef] [PubMed]

50. Hristov, A.N.; Oh, J.; Firkins, J.L.; Dijkstra, J.; Kebreab, E.; Waghorn, G.; Makkar, H.P.S.; Adesogan, A.T.; Yang, W.; Lee, C.; et al. Special topics-Mitigation of methane and nitrous oxide emissions from animal operations: I. A review of enteric methane mitigation options. Sci. J. Anim. Sci. 2013, 91, 5045-5069. [CrossRef] [PubMed]

51. Muñoz, C.; Hube, S.; Morales, J.M.; Yan, T.; Ungerfeld, E.M. Effects of concentrate supplementation on enteric methane emissions and milk production of grazing dairy cows. Livest. Sci. 2015, 175, 37-46. [CrossRef] 
52. Zhao, Y.G.; Aubry, A.; O'Connell, N.E.; Annett, R.; Yan, T. Effects of breed, sex, and concentrate supplementation on digestibility, enteric methane emissions, and nitrogen utilization efficiency in growing lambs offered fresh grass. Anim. Sci. J. 2015, 93, 5764-5773. [CrossRef]

53. McCaughey, W.P.; Wittenberg, K.; Corrigan, D. Impact of pasture type on methane production by lactating beef cows. Can. J. Anim. Sci. 1999, 79, 221-226. [CrossRef]

54. Hammond, K.J.; Hoskin, S.O.; Burke, J.L.; Waghorn, G.C.; Koolaard, J.P.; Muetzel, S. Effects of feeding fresh white clover (Trifolium repens) or perennial ryegrass (Lolium perenne) on enteric methane emissions from sheep. Anim. Feed Sci. Technol. 2011, 166, 398-404. [CrossRef]

55. Dini, Y.; Gere, J.I.; Cajarville, C.; Ciganda, V.S. Using highly nutritious pastures to mitigate enteric methane emissions from cattle grazing systems in South America. Anim. Prod. Sci. 2017, 58, 2329-2334. [CrossRef]

56. Pulina, G.; Rassu, S.P.G.; Bencini, R. Relation between birth weight of lambs and milk production in ewes. Stoč. Čas. Unapr. Stoč. 1996, 50, 199-203.

57. King, G.J.; Thatcher, W.W. Pregnancy. Reprod. Domest. Anim. 1993, 9, 229-266.

58. Alexander, G.; Davies, H.L. Relationship of milk production to number of lambs born or suckled. Aust. J. Agric. Res. 1959, 10, 720-724. [CrossRef]

59. Gardner, R.W.; Hogue, D.E. Effects of energy intake and number of lambs suckled on milk yield, milk composition and energetic efficiency of lactating ewes. Sci. J. Anim. Sci. 1964, 23, 935-942. [CrossRef]

60. Petersen, B.M.; Knudsen, M.T.; Hermansen, J.E.; Halberg, N. An approach to include soil carbon changes in life cycle assessments. J. Clean. Prod. 2013, 52, 217-224. [CrossRef]

61. Batalla, I.; Knudsen, M.T.; Mogensen, L.; del Hierro, Ó.; Pinto, M.; Hermansen, J.E. Carbon footprint of milk from sheep farming systems in Northern Spain including soil carbon sequestration in grasslands. J. Clean. Prod. 2015, 104, 121-129. [CrossRef]

62. Barron, L.J.R.; Andonegi, A.; Gamboa, G.; Garmendia, E.; García, O.; Aldai, N.; Aldezabal, A. Sustainability assessment of pasture-based dairy sheep systems: A multidisciplinary and multiscale approach. Sustainability 2021, 13, 3994. [CrossRef]

63. Sanna, F.; Campesi, G.; Deligios, P.; Ledda, L.; Piluzza, G.; Sulas, L.; Re, G.A. Combined effects of microenvironment and land use on C fluxes in a Mediterranean agro-silvopastoral system. Eur. J. Agron. 2021, 130, 126348. [CrossRef] 